The Limits to Community-based Conflict Resolution in North-East Congo

Niamh Gaynor

Email: niamh.gaynor@dcu.ie

Telephone: 00-353-1-700-6048

Author:

Dr. Niamh Gaynor is a Lecturer in the School of Law and Government, Dublin City University, Glasnevin, Dublin 9, Ireland. 


\title{
The Limits to Community-based Conflict Resolution in North-East Congo
}

\begin{abstract}
The Democratic Republic of the Congo (DRC) is the site of one of the most egregious conflicts in modern times. Fuelled by a violent political economy of mineral and natural resource extraction, the lengthy cycle of violence and intimidation has resulted in the highest death toll in any war since World War II. The shortcomings of internationally sponsored peacebuilding efforts in the region have led to a local turn in the peacebuilding literature where a key role for community groups in local conflict resolution and development is being promoted.
\end{abstract}

Drawing on fieldwork conducted by the author with community groups in Ituri District in north-eastern DRC, this article highlights the failure of international and national initiatives to address the underlying causes of the Iturian conflict and goes on to argue that there are limits to what local communities can achieve in this context. The findings demonstrate that the greatest impact of community groups' activities is at individual rather than structural levels and three inter-related reasons are given for this. The article concludes by highlighting four issues for community groups interested in challenging the status quo and effecting longlasting transformative change, moving from conflict containment to conflict transformation. 


\section{Introduction}

The 'Congo wars' of the 1990s, and their aftermath are widely regarded as some of the most complex and egregious conflicts of our time. Fuelled by a violent international political economy of extraction and exploitation, the wars have generated levels of suffering that are unparalleled in any recent war and have caused, directly and indirectly, the highest death toll of any conflict since World War II. By 2007 an estimated 5.4 million people had died with an estimated one thousand innocent civilians dying every day (International Rescue Committee 2007) although these figures are disputed by some (see Lambert and Lohlé-Tart 2008 in Trefon 2011: 60). Millions more were displaced as they fled the violence, with an estimated three million people remaining internally displaced as of 2014 as violence and insecurity continues, in particular in the east of the country (UNHCR, 2014). Sexual violence against women and children has been widespread and disease and malnutrition rampant (Baaz and Stern 2013). A high level of regional and national instability has resulted, leading to widespread personal insecurity which persists to the present.

Some of the bloodiest fighting and the gravest atrocities took place in the resource-rich district of Ituri in north-eastern DRC. During the worst years of the conflict here, from 1999 to 2003 , an estimated 50,000 to 60,000 people were killed and a further 500,000 were displaced (HRW, 2003; Amnesty International, 2003: 15) as local rebel groups and warlords joined forces with Ugandan and Rwandan actors and networks to gain control of the district's mineral wealth. While the fighting has since abated, the legacies of the war continue and low lying insecurity (banditry and looting) remains a feature of daily life in many areas with more widespread violence resurging in the district capital Bunia in 2012 (author interviews Bunia; see also OCHA, 2014). 
The United Nations' (UN’s) peacekeeping mission in the DRC, now, at $\$ 8.7$ billion, the largest and most expensive operation in the UN's history, has been widely criticised as an expensive (in terms of local lives and livelihoods as well as investment) failure (Englebert and Tull 2008; Eriksen 2009; Trefon 2013). The reason for this is its emphasis on regional stability and its neglect of local tensions and animosities. As Autesserre, in her detailed, comprehensive and compelling analysis of the UN's mission in the DRC notes (2010: 95), 'the main reason that the peace-building strategy in Congo has failed is that the international community has paid too little attention to the root causes of violence there: local disputes over land and power'. She, together with a range of other commentators (Kisangani 2006, 2010; Engelbert and Tull 2008; Trefon 2011; Larmer et al 2013), has called for greater support to more locally rooted, community-based peacebuilding initiatives.

These locally rooted, community-based initiatives are the focus of this article. Drawing on fieldwork conducted by myself among seven diverse communities in Ituri in August, 2014, I highlight a number of challenges facing local groups in their attempts to assist their communities and to manage local conflicts. Fieldwork included interviews with development agency (local and international) representatives in the district capital Bunia, together with interviews and focus group discussions (FGDs) with community group members, non-group members and local political authorities across seven different sites within the district. The seven sites were both ethnically and geographically (urban/rural and in terms of resource wealth) diverse. In total, interviews were held with seven agency representatives at district level and, in the sites visited, with 13 local authorities (including 2 women); 88 members of local community groups in focus group discussions (65 women and 23 men); 17 members of local community groups in individual interviews (13 women and 4 men); and 22 randomly selected community members (11 women and 11 men). All interviews and FGDs were 
carried out by myself, with translation from local languages to French provided by local translators. Back in Ireland, I transcribed and translated (from French to English) all interviews and FGDs in full. Within the article, I go on to discuss four key issues for community groups and their supporters interested in moving from a more survivalist to a more transformative role - i.e. from conflict containment to conflict transformation, challenging the exploitative and, at times, divisive social norms and structural inequalities underpinning local tensions and animosities. The article, although primarily aimed at those supporting local community mobilisation and peacebuilding initiatives, is also relevant to broader contemporary debates on community resilience where the emphasis on local agency tends to ignore the broader structural constraints and limitations to its exercise (see for example Chandler, 2012; World Bank 2013; and UNDP 2014).

\section{Conflict minerals and war in Ituri}

Taking its name from the Ituri river, Ituri is one of five districts of Orientale Province in the north-east of the DRC and shares a border with both Uganda and Sudan. It is richly endowed with highly fertile land, pristine forests, large gold deposits, both fish and oil reserves in Lake Albert and also deposits of diamonds and coltan (Pottier, 2003; IKV Pax Christi and RHA, 2012; Fahey, 2013). Ituri has a surface area of approximately $65,000 \mathrm{~km}^{2}$ and a population of over four million. There are ten principle ethnic groups, with the Alur (27\%) mainly concentrated in Mahagi; whereas the Lendu (24\%) and Hema (18\%) are in the territories of Djugu and Irumu (the two territories included in this study); and the Lugbara (12\%) are concentrated in the Aru territory (IKV Pax Christi and RHA, 2012: 9). 
Although conflict has waged in Eastern Congo since 1996, Ituri was the scene of some of the bloodiest fighting and gravest atrocities in the DRC between the years 1999-2003. Some dozen non-state armed forces emerged during this time. Many of these were organised along ethnic lines and, exploiting local tensions and animosities, incited significant sections of the local population to violence (UNSC, 2002; Anten, 2010). While the most intense period of conflict was from 1999-2007, violence resurged in Bunia in 2012 and violence and unrest continue in South Irumu territory at the time of writing (see also OCHA, 2014).

Conflict in Ituri, while closely linked to ethnic-based conflict in the neighbouring provinces of North and South Kivu, is also rooted in a history of mineral and natural resource exploitation. For over 150 years foreign military and commercial interventions in the area have aggravated local rivalries and tensions, politicising ethnic relations and increasing the likelihood of grievance-based conflict. As Fahey (2013) notes, the decisions by local leaders to either collaborate or to resist incursions into Ituri - initially for ivory and slaves, and later for gold and land - has had a profound impact on local relations within the district.

The two principal internal drivers of the recent Iturian war were unequal access to land (and its resources) and a high level of social stratification which, through multiple deeply entrenched regional, ethnic and gendered hierarchies of superiority and inferiority, fuelled tensions and grievances as well as egregious acts of sexual violence during the war. Land conflicts have existed since the colonial era when Belgian agents appointed local Chiefs, redrew boundaries and physically separated populations (Hochschild, 2008; Fahey, 2013). Following independence, disputes over land rights, access and ownership became incorporated into local struggles for political and economic power - notably between the pastoralist Hema and the agriculturalist Lendu ethnic groups (Pottier, 2003; Vlassenroot and 
Raeymaekers, 2004; RCN, 2009; Huggins 2012). These struggles have been fuelled by a vast mineral wealth, comprising mostly gold, timber and oil, with local elites colluding with national and international (predominantly Ugandan and Rwandan in the first instance and on through complex supply chains into Europe and the US) actors in extracting the benefits of this wealth to the exclusion of the majority of the Iturian population (Anten, 2010; Fahey, 2013). Yet, as the following section demonstrates, international and national responses to the war - both peacekeeping efforts and efforts to regulate mining - have neglected community concerns and sources of local tension.

\section{International and national responses to Ituri's war}

In 2003, at the height of the Ituri war, an EU-led military intervention was launched into the district capital, Bunia. The initial three month operation, named Artemis, paved the way for the subsequent UN Mission in the Congo named MONUC (later, with a broader stabilisation mandate, re-named MONUSCO). Over the coming years this international intervention succeeded in bringing a degree of stability to the region as it neutralised rebel forces.

However, its abject failure to protect civilians from direct attacks in towns and villages across the district has been strongly criticised (Clark, 2011; Copeland, 2012). Moreover, the accompanying process of Disarmament, Demobilisation and Reconstruction (DDR) aimed at disarming and reintegrating rebels was disorganised and ultimately largely ineffective as it became mired in institutional turf wars and corruption scandals (Bouta, 2005; Veit, 2010; author interviews with local implementing agencies, 2014). As one local NGO representative notes, 'It [DDR] was carried out as an emergency programme. And the problem started there. A systematic analysis was not done, and that is why it has failed. They did train people [ex-combatants], they gave them a little bit of equipment, technical materials. But there is very little need in the village for that [equipment and material provided]. So there was a 
certain level of in-adaptation in the service that was given to the demobilised, that's from one side. On the other side, gross amounts of money were injected, but were mal-managed.' Another local NGO representative is even more direct on the issue of resources. 'The sum that we were given for the reinsertion of the ex-combatants, only four per cent of the money went to the population and the rest was in their [funding and implementing agencies'] pocket... There is a system established between certain agents of the funding structures [funding agencies] with the executors [implementing agencies] of the [DDR] projects. They call it 'Operation Retour' [Return Operation]. They give you money and you return ten per cent, fifteen per cent or twenty per cent to the person [funding agency representative]. But they don't do any work to justify it, it is pure theft.'

Perhaps most significantly however is the fact that international efforts aimed at stabilising the region have failed to address in any way the local drivers of conflict including those arising from ongoing illegal mineral and natural resource appropriation by networks of local, national and international actors (Anten, 2010; Autesserre, 2010; Tamm, 2013b; Hellmueller, 2014). As the RCN (2009: 9) puts it, Ituri today is 'a zone of neither war nor peace' with the exploitation and expropriation of the district's natural resources by new networks of internal and external 'resource entrepreneurs' (Vlassenroot and Raeymaekers, 2004: 385) continuing apace. The continued failure to address the ambiguous and easily manipulated land tenure laws leaves a legal vacuum whereby powerful vested interests override the rights of ordinary Iturians seeking to sustain a livelihood for their families (author interviews NGO representatives and focus group discussions, 2014; see also RCN, 2009). The illegal timber harvesting in the forests of Mambasa (author interview and correspondence RCN, 2014); the insecurity around the gold mines towards which former militias are increasingly gravitating (companies are reported to include the British companies Kibali Gold Mines, Ashanti Gold 
Kilo (AGK), Auris Gold and Kilo Gold; the British and South African company, Muana Africa; and the Canadian company Loncor - author interviews Kilo and RCN, 2014; see also IKV/RHA, 2012), and local tensions around the secret oil deals reportedly signed between Kinshasa and a range of international oil companies for prospecting rights in Lake Albert (companies are reported to include Heritage Oil, Tullow Oil, Total, Divine Inspiration Consortium, H-Oil Sud, Congo Petroleum and Gas, Caprikat and Foxwhelp (Pottier, 2003; Cafod and Trocaire, 2012; author interviews RHA and RCN)) all serve to fuel local grievances as communities witness ongoing external appropriation of their wealth.

A World Bank sponsored Mining Code was introduced by the national government in 2002. This aimed at formalising the mining sector and turning it into one of the principle drivers of the country's economy. However, in common with similar reform programmes throughout the sub-continent (see Pegg, 2003; Hilson and Yakovleva, 2007; Campbell, 2011), it neglects the concerns and interests of local communities. Moreover Trefon (2013, 41-42), drawing on the findings of a review of 61 mining deals within the DRC between the years 2006 and 2009, concludes that the government has not increased its transparency in this area and that secret negotiations remain the norm. This has certainly been the experience in Ituri where local activists, working with local community groups, have failed - despite robust efforts - to secure information on oil mining companies operating locally. Both local communities and provincial authorities have been side-lined in deals negotiated directly with government authorities in Kinshasa. As one local NGO representative notes, 'here all we saw was companies arriving with military personnel, with jeeps, with their arms. We saw these companies but we did not know who they were'. 
While communities in other countries are often afforded some space to voice their grievances and demands in the context of the activities of mining and extractive industries in their communities (see for example, Kemp, 2010; Ackah-Baido, 2013; Machonaschie and Hilson, 2013), in Ituri the activities of such companies remain clandestine and hidden (author interviews with community groups, RCN and RHA, 2014). Even where local people have managed to uncover who some of the companies are and where they are based locally, it has proven impossible to secure a meeting to gather any further information on their activities. A local NGO representative outlines the problem, 'Because the company in Block One and Two, it is a company that is very in flux [constantly moving]. It is very hard to know who is responsible. They opened an office here even. But if you go to the office you will find a Guard, but there are no people inside. And each time we called them to try to have a meeting, we got no response’.

With EU and UN responses to the war aimed at regional stability through elite political settlements and therefore failing to address and, in some cases, exacerbating local tensions, attention among commentators and practitioners alike is now turning to local community capacity to manage these tensions. The remainder of this article draws on research in seven diverse communities examining their experiences and challenges in attempting to do so.

\section{Community responses}

One of the consequences of the Iturian war, in common with many other post-conflict contexts, was the emergence of local non-governmental organisations (NGOs) supported by an influx of international humanitarian agencies. These local NGOs sought to work through pre-existing community structures, establishing their own local structures where necessary. 
Necessarily, their immediate aim was to assist families and communities to survive through the horrors of the war and its aftermath - the two main activities were conflict management between local ethnic groups ('pacification') and, for women's groups, assisting victims of sexual violence to seek medical attention and psychological support. Groups studied for this research range from those established at this time to those established more recently. These include women's groups, mixed male-female groups and groups with mixed ethnic make-ups. Yet, despite these differences in evolution and constituency, the main impacts of all groups remain very much at individual levels - addressing the symptoms rather than the causes of local conflicts and development challenges. The principle activities today are local conflict management and assistance to victims of sexual violence, as well as local development and community sensitisation on a number of issues - including women's rights.

In this regard, group members have provided valuable assistance to select friends, family members and neighbours, as well as benefitting from membership themselves. For example, as the excerpt from a female group member below demonstrates, the training in women's rights provided to the group by the supporting NGO facilitated her in defending her own rights against a customary forced marriage following the death of her husband.

I am a widow. After the death of my husband, following the custom, they [husband's family] had prepared a brother of my [late] husband who was now to be my husband. But thanks to the training, on the rights of the widow, I defended myself in front of the family who wanted to give me a husband by force and I defended my own rights and those of my children.

(Female FGD participant, Site A)

Other group members use such training to try to assist other women 'victims' of sexual violence in their village. 
There are men who refuse to live with women who have been victims of sexual violence. Even though they have followed their [medical] treatment. So we have identified these men and we would like to invite these men and to speak to them so that they will not abandon their women. It is not these women who wanted to be victims but it is just the consequence of war.

(Individual interview, Female group member, Site D)

While there have been attempts to address broader structural issues, these have involved approaches to local individuals rather than addressing their broader structural causes of the problem. For example, one of the greatest economic difficulties for families is managing to pay local school 'fees' (The lack of state investment in education, as in all other social sectors, means that teachers' salaries remain extremely low and sporadic and there is no public infrastructural expenditure. Education has consequently been, de facto, privatised. In the sites visited, primary school 'fees' are approximately $\$ 3 /$ month; secondary school fees approximately $\$ 6 /$ month; and university fees approximately $\$ 450$ per annum). Yet, although the root of the problem is complex and multilayered, the local group's solution is to try to negotiate with the local school authorities rather building support to demand redress further up the line.

Me: And for the payment for education, do you think it is something that you could influence? Could the group do something about this?

Yes, [group E] could involve itself. Because we are participants of governance. We should talk to the managers of the school to debate the issue. Lately here, there is no money in the hands of the population. Each day that the cost of living goes up, to have money is very difficult. So [group E] could involve itself in the negotiation of the payment of education. Because there is no money, because soon there will be very few children in school.

(Individual interview, male group member, Site E)

A similar approach is seen with another group attempting to tackle the (illegal) issue of road 'taxes' imposed by the armed military who continue to be deployed in the area due to ongoing low levels of insecurity. Rather than mobilising public support against this 
continued exploitation of the population, the strategy is to tackle the issue through individual channels, with the problem identified being the multiplicity of such blockades rather than their existence per se.

Another thing that we try to change were the blockades set up by the military on the roads. We tried everything to change these but that has not worked.

Me: And what did you do to try to change this?

We did a lot of lobbying to the Commander of the military but that didn't work.... We pay that [the fee imposed for passage at the road blocks] from fear because they can also shoot you if you do not pay. The biggest problem is there is a multiplicity of these blockades. So if you are going a long distance you are obliged to pay the Fr.500 per blockade and it becomes very expensive.

(Female FGD participant, Site A)

These findings, which point to important impacts at individual levels but little in the way of broader structural and political impacts addressing the ongoing legacies and causes of local conflicts, beg the question as to why this is so. Drawing again from fieldwork, three interrelated factors are proposed which help explain the limited broader transformative impact of community groups' actions. These are the relations of groups with their local political authorities; their framing of local issues and difficulties; and their relations with their broader communities.

\section{Relations with local authorities: Consolidating rather than contesting unequal relations}

As we have previously seen, the local drivers of conflict - unequal access to land and resources fuelled by networks of local, national and international actors - remain. Embedded to varying degrees within these networks, local authorities remain unwilling or unable to challenge these and the exploitation and marginalisation of local communities continues apace. Yet, both community group members and local authorities identify their roles as working in collaboration with rather than in opposition to each other, surviving within rather 
than transforming an inherently unjust and dislocating system. Some excerpts from interviews and focus group discussions illustrate this approach.

Our role is to see the evolution of the village and, if there is a problem, then we will involve the Chief of the area directly... Before we did not work with the Chief. But now we work with Chief. So now if we want to construct a house, we do this with the Chief.

(Female FGD participant, Site E)

We come to give him [Village Chief] a report on how we have managed the conflicts if he is not present.

(Female FGD participant, Site A)

We count on sensitising the population on how the population can pay the state tax, this is already planned, and we have discussed this with the local authority so he will allow this. And also, another theme [for our sensitisation] is that the population supports the plan of development put forward by the Chief - the construction of bridges, the construction of schools, where the community can contribute to bringing the something for the construction, that is what we have planned.

(Male FGD participants Site G)

These women [the local women's community group] do sensitisation in the village. They organise meetings with women and with the women Chiefs [village women nominated by the village Chief to work on his behalf] in each village. They sensitise them on cleanliness, on how they should comport themselves, on how they should maintain their village and their field. They sensitise for sanitation... If there are problems with women, if these problems are brought to the village Chief he calls the woman Chief to deal with these problems with the women.

(Interview village chief, Site F)

Moreover, one of the key benefits of community group membership identified by members is the enhanced status and prestige accrued from these closer relations to authorities.

The advantage of being a member is that we are closer to the power... As a member of [group G], I am given an honour on the road [I am respected], the military people, the police. I am known as a member of this association.

(Male FGD participant, Site G) 
What impresses me the most is the relationship with the authorities. At the start I was afraid of these people. But when I am at the head of the group, in meetings for example, I speak. People know me. And even people when they meet me on the road, they say ' $E$ [name of group] how are you?'. I am very proud of that.

(Individual interview, Female group member, Site E)

Operating in collaboration with local authorities, the role of community groups therefore appears to be to reconcile people to their world, rather than to contest and transform it. Their actions as what we might perceive as parallel authorities in this regard, risk reproducing and consolidating existing inequalities and hierarchies of authority, knowledge and power, thereby supporting rather than challenging and transforming these political institutions and the broader networks in which they are embedded. As we now see below, this is reinforced by a framing of local challenges and difficulties which emphasises personal responsibility over political factors.

\section{Framing local problems: Collective rights through personal responsibility}

Although not necessarily a conscious strategy employed by groups, local problems are framed in two principle ways by groups. Significantly, these focus on how to address problems (prognostic) rather than exploring their causes (diagnostic). The frames employed employ both a legal discourse and a discourse of personal responsibility.

The legal frame is very common and appears extremely effective - most particularly in relation to both the issues of women's rights and in relation to raising debate on the issue of gender-based violence (GBV). Drawing from the explicit rights-based approach employed by many NGOs, it focuses on provisions within the Constitution, and training on this has been provided by supporting NGOs to community group members. In a context where the 
law appears to have some influence on norms and behaviours at local levels (if not at provincial or national), group members have made much use of this framing in shaping attitudes and behaviours. The following excerpts provide a little more detail on how this is done.

Before 2008 [when the group was established and trained] men did not listen to women. They did not consider them. But after 2008, with the installation of our group by the RHA and the training of FOMI[NGOs], people are now more convinced. What has convinced them the most is what is in the Constitution. So that is what convinces them. Even if they are not happy with this [talk of women's rights], they do listen to us.

(Individual interview, group member, Site E)

Before the custom did not allow us women to sit with men but now, after the Constitution openly authorised this, we take our responsibility and we sensitise other women so that they will work with men.

(Female participant FGD, Site C)

The second frame employed is people's own responsibility, in particular in relation to local development, but also in relation to women's parity and GBV. A male advisor to the women's group in Site C frames the group's role in this light.

Me: What is the role of your group?

As I understand it, it is to bring up the women who are in the home. These women are chosen to develop themselves. They go everywhere in the villages to sensitise other women, to give them advice and pressure them on what they cannot do themselves. So they help them to develop themselves - on sanitation for example. They do all the development of the village. Together with the Chief, they are there for the development of the village.

(Male FGD participant (advisor to women's group), Site $\mathrm{C}$ - emphasis added) 
While the rights-based approach with its strong legislative basis proves an extremely powerful frame within the community, the emphasis on personal responsibility leaves no scope to explore or interrogate the responsibilities of state structures and authorities or their broader international networks. This is also evident in the reinforcement of gender-based hierarchies of knowledge and authority, and in the persistent framing of gender inequalities in personal rather than structural terms. As the excerpt from a male advisor to the women's group in Site D outlines, difficulties are women's own and the responsibility for addressing them are also women's own. Notwithstanding this, the advisors (as the appellation suggests) appear to have superior knowledge to women on how to do this.

We support the women to reinforce their capacity around the different trainings that we have received from FOMI. We are here to hold sensitisations. The essential thing for the women is that they come out of obscurity ....I am interested in accompanying the women because they have a lot of information to impart - all their difficulties. We can also show them an orientation, to show them - 'how will you do to address your issues?' [how to address your issues].

(Male FGD participant (advisor to women's group), Site D - emphasis added)

Solutions to systemic problems are promoted within a political and cultural vacuum. As such, they tend to address symptoms rather than causes. At best, such solutions can lead to some temporary respite for some but, at worst - notably in relation to the framing of women's rights as being women's sole responsibility - they can add to the already significant demands (physical and psychological) on individuals' and families' energy and resources. In addition, with the responsibilities and agency of political authorities rendered all but invisible and the same problems and conflicts doomed to repeat themselves, people's tendency to vent frustration and anger at the ethnic / gendered / regional 'other' is exacerbated.

Relations with local communities: Talking 'at' rather than 'with' and failing to mobilise networks of solidarity, support and change 
A third factor contributing to the non-transformationalist nature of community group engagement is the nature of community groups' relationships with other community members. The focus is on information provision and sensitisation rather than mediation and mobilisation (talking at rather than listening to). As the excerpt below illustrates, aimed at individual and collective behavioural change, this is intertwined with the framing of issues in terms of personal responsibility. The excerpt refers to a common problem in all sites - that of 'the night market' / 'la marché nocturne'. Although framed in terms of personal responsibility for going to the market before dark, the problem is actually one of sexual assault and rape - the incidence of which increases after dark. The consequences of this framing are apparent from the response of one group who, when asked if men should also be sensitised on this issue, after a pause responded that yes, men can also, in rare cases, be subject to assault.

What we do the most regularly with the community are sensitisations. We sensitise people to discourage them from going to the market at night because here people have the habit of going to the market late ${ }^{1}$.

We also did sensitisation in three villages on how to avoid it catching the illness HIV/AIDS

Me: when you do sensitisations, why do you do sensitisations? What is the aim of this?

\section{To change the mentality, to wake the population.}

(Participants in FGD Site A- emphasis added)

This almost exclusive and ubiquitous focus on sensitisation leaves little scope to explore perceptions, experiences and analyses of community members, to formulate strategies around these, and to work together to address them. In short, it misses valuable opportunities to explore and imagine alternative futures and to build coalitions of support for these. 
Overall, the findings presented in this section demonstrate that local community groups' activities to date are aimed at surviving within rather than transforming the extractive, exploitative system which underpinned the war and which continues today. Community mobilisation in this context aims at reconciling communities to this system rather than building coalitions of solidarity and support to challenge and transform it. In this context, there are significant limits to what communities can achieve and the international community's excessive reliance on community-based conflict resolution whilst not tackling the broader structural causes of this conflict appears unrealistic and misplaced.

\section{Conclusion}

The Ituri war was a war of greed and grievance. Fuelled by networks of local, national and international actors, it was underpinned by an inherently unequal and unjust socio-political system. This system remains. And so, the underlying drivers of conflict remain. Life, for the majority of Ituri's citizens struggling to rebuild their homes, lives and livelihoods following the devastation of the war, remains difficult, insecure and precarious.

While the admirable achievements of the community groups examined deserves due recognition, operating as they do in extremely difficult and challenging circumstances and rendering important and, in some cases, life-saving services to friends and neighbours, their transformative potential also merits further reflection. In a context where the existing political system is clearly failing its people and where a new politics is required, community groups such as these can function as political laboratories where members can develop and consolidate their skills in argument formulation, debate, mediation, negotiation and 
bargaining - skills, in other words, to equip them to contest local structures and to engage with wider political interest groups in forging a new, more inclusive and democratic politics. Drawing on such a vision, four issues which draw from the findings reported above are pertinent.

First, in terms of framing, how can the framing of issues/problems/conflicts be broadened from prognosis alone (how to manage) to a diagnosis of their root causes? Second, in terms of responsibilities, how can the field be broadened from individuals' responsibilities to those of economic and political structures and authorities? Third, in terms of women's rights, how can the approach be broadened from the apolitical 'add women and stir' approach of the 1980s to one which interrogates the root causes of women's marginalisation and discrimination in the context of roles and hierarchies inscribed in and reproduced by dominant social norms, practices and discourses? And fourth, in terms of community mobilisation, how can groups move from sensitisation alone to collaboration with community members and individuals to build networks of solidarity and support in challenging and transforming inherently inequitable systems and structures?

The evidence of the past ten years demonstrates that greater equality, justice and freedom for Iturians will not come from the top down. It has to be forged from the bottom up. And, in a context where this has never been allowed or facilitated, this requires both space to imagine political alternatives and it requires coalitions of solidarity and support to bring them about. The challenges in developing such spaces and coalitions are certainly significant, but in a context where the root causes of the war remain simmering beneath the surface, the costs in not doing so are most certainly more.

\section{Bibliography}

Ackah-Baidoo, A. (2013) "Fishing in troubled waters: Oil production, seaweed and community=level grievance in the Western Region of Ghana, Community development Journal, 48(3), 421-436. 
Amnesty International (2003) Democratic Republic of Congo: "Our Brothers Who Help Kill Us" - economic exploitation and human rights abuses in the east. July 2003, http://web.amnesty.org/library/print/ENGAFR620102003.

Autesserre S. (2010) The Trouble with the Congo: Local Violence and the Failure of International Peacebuilding, Cambridge, Cambridge University Press.

Anten, L. (2010) Strengthening governance in a post-conflict district of the Democratic Republic of the Congo: A study of Ituri, The Hague, The Conflict Unit, Netherlands Institute for International Relations.

Baaz, M. E. and M. Stern (2013) Sexual Violence as a Weapon of War, London, Zed Books.

Bouta, T. (2005) Assessment of the Ituri Disarmament and Community Reinsertion Programme (DCR), The Hague: The Conflict Unit, Netherlands Institute for International Relations.

Cafod and Trócaire (2012) Oil extraction in Lake Albert: Briefing booklet, available at http://www.mileslitvinoff.info/dcs/Lake-Albert.pdf.

Campbell, B. (2011) "Corporate Social Responsibility and development in Africa: Redefining the roles and responsibilities of public and private actors in the mining sector", Resources Policy, doi:10.1016/j.resourpol.2011.05.002.

Chandler, D. (2012) "Resilience and Human Security: The Post-Interventionist Paradigm", Security Dialogue, 43(3), 213-229.

Clark, Janine Natalya (2011) "UN Peacekeeping in the Democratic Republic of Congo: Reflections on Monusco and its Contradictory Mandate", Journal of International Peacekeeping, 15(3-4), 363-383.

Copeland, Thomas F. (2012) "Civilian protection in the Eastern DRC: Evaluation of the MONUSCO Peacekeeping Operation”, MA thesis, Monterey, California: Naval Postgraduate School.

Englebert P. and D. M. Tull (2008) "Postconflict Reconstruction in Africa: Flawed Ideas about Failed States", International Security 32(4), 106-139.

Eriksen S.S. (2009) "The Liberal Peace Is Neither: Peacebuilding, State building and the Reproduction of Conflict in the Democratic Republic of Congo", International Peacekeeping 16(5), 652-666.

Fahey, D. (2013) Ituri: Gold, land and ethnicity in north-eastern Congo, London and Nairobi, Rift Valley Institute.

Hellmueller, S. (2014) "A story of mutual adaptation? The interaction between local and international peacebuilding actors in Ituri” Peacebuilding, 2(2), 188-201.

Hilson, G. and N. Yakovleva (2007) "Strained relations: A critical analysis of the mining conflict in Prestea, Ghana", Political Geography 26, 98-119.

Hochschild, A. (2008) King Leopold's Ghost: A Story of Greed, Terror, and Heroism in Colonial Africa, Macmillan, Basingstoke. 
Huggins, C. (2012) Land, Power and Identity: Roots of violent conflict in eastern DRC, London, International Alert.

Human Rights Watch (2003) 'Ituri: 'Covered in Blood': Ethnically Targeted Violence in Northeastern DR Congo", HRW Publications 15(11), http://www.hrw.org/reports/2003/ituri0703/.

Human Rights Watch (2005) The Curse of Gold: DRC, New York, HRW Publications.

International Rescue Committee (2007) Mortality in the Democratic Republic of the Congo: An Ongoing Crisis, New York, IRC.

IKV Pax Christi and Réseau Haki Na Amani (2012) A Golden Future in Ituri? Which perspective for gold exploitation in Ituri, DR Congo, Utrecht, IKV Pax Christi.

Kemp, D. (2010) "Mining and community development: problems and possibilities of locallevel practice”, Community Development Journal, 45(2), pp. 198-218.

Kisangani, E. F. (2006) "Legacies of the war economy”, in M. Nest, F. Grignon \& E.F Kisangani, eds., The Democratic Republic of the Congo: Economic dimensions of war and peace. New York, International Peace Academy.

Kisangani E. F. (2010) Civil Wars in the Democratic Republic of the Congo: 1960-2010, Lynne Rienner, Boulder, Colorado.

Larmer M., Laudati A. and J. F. Clark (2013) "Neither war nor peace in the Democratic Republic of the Congo (DRC): profiting and coping amid violence and disorder", Review of African Political Economy 40(135), 1-12.

Machonachie, R. and G. Hilson (2013) "The extractive industries, Community development and livelihood change in developing countries", Community Development Journal, 48(3), 347-359.

OCHA (2014) DR Congo: Humanitarian Snapshot (July 2014), Office for the Coordination of Humanitarian Affairs, available at http://reliefweb.int/report/democratic-republiccongo/dr-congo-humanitarian-snapshot-july-2014.

Pegg, S. (2003) "Globalisation and Natural Resource Conflicts", Naval War College Review, Autumn 2003, 56(4), 82-96.

Pottier, J. (2003) "Emergency in Ituri, DRC: Political complexity, land and other challenges in restoring food security", Paper presented at the FAO international workshop, Tivoli, 23-25 September, 2003.

RCN Justice et Démocratie (2009) Les Conflits fonciers en Ituri: De l'imposition à la consolidation de la paix, Bruxelles, Kinshasa and Bunia, RCN Justice et Démocratie.

Tamm, H. (2013) FNI and FRPI Local resistance and regional alliances in north-eastern Congo, London and Nairobi, Rift Valley Institute. 
Trefon T. (2011) Congo Masquerade: The Political Culture of Aid Inefficiency and Reform Failure. Zed Books, London and New York.

Trefon T. (2013) "Uncertainty and powerlessness in Congo 2012", Review of African Political Economy, 40(135): 141-151.

United Nations Development Programme (2014) Sustaining Human Progress: Reducing Vulnerabilities and Building Resilience, New York: UNDP.

United Nations Humanitarian Committee for Refugees (2014) 2014 UNHCR country operations profile - Democratic Republic of the Congo, available at http://www.unhcr.org/pages/49e45c366.html.

United Nations Security Council (2002) Final Report of the Panel of Experts on the Illegal Exploitation of Natural Resources and Other Forms of Wealth of DR Congo, Report S/2002/1146, October $16^{\text {th }}, 2002$, available at http://www.un.org/News/dh/latest/drcongo.htm.

Veit, A. (2010) Intervention as Indirect Rule: Civil War and Statebuilding in the Democratic Republic of the Congo, Frankfurt: Campus publications.

Vlassenroot, K. and T. Raeymaekers (2004) “The Politics of Rebellion and Intervention in Ituri: The Emergence of a new Political Complex?", African Affairs, 103(142), 385-412.

World Bank (2013) Building Resilience: Integrating Climate and Disaster Risk into Development, Washington DC: World Bank. 